\title{
The socio-pedagogical conditions of the formation of high school students' social competence in the space of non-formal education: a practical aspect
}

\author{
M. Fedoruts \\ Volodymyr Hnatiuk Ternopil National Pedagogical University \\ Corresponding author. E-mail: showman3007@gmail.com, ORCID ID: 0000-0003-2788-0557
}

Paper received 02.09.20; Accepted for publication 24.09.20.

\begin{abstract}
https://doi.org/10.31174/SEND-PP2020-236VIII94-06
\end{abstract}
\begin{abstract}
The socio-pedagogical conditions of the formation of high school students' social competence have been characterized (including stimulation of the subjective position of high school students, providing socio-pedagogical support and monitoring; modernization of the content, forms and methods of non-formal education; organization of the amateur space and assistance). The implementation of the outlined socio-pedagogical conditions in the space of non-formal education has been established to promote the development of students' motives for success, social intelligence, social activity and social values, encouraging the process of formation of the social competence of high school students as the subjects of self-knowledge, self-development and self-realization.
\end{abstract}

Keywords: socio-pedagogical conditions, non-formal education, social competence, high school students.

Introduction. The departure from the formalized and institutionalized educational systems towards informal and nonformal ones has caused the processes of liberalization and humanization of education in the developed countries during the recent decades. At the same time, non-formal education is largely aimed at the socio-personal development of its subjects, the satisfaction of their social interests, social appeals and needs of a personality in the professional definition. Taking it to consideration, the target priority of the system of the non-formal education in Ukraine should be the formation of a socially competent personality. This type of education is supposed to be open to all the pupils, where they may find themselves, realize themselves, choose their educational trajectory and acquire the key competencies, necessary for successful social and personal self-realization.

Analysis of the recent publications. The analysis of the scientific literature testifies to the accumulated experience of the investigation of the social competence of a personality, the conditions and factors of its formation. Thus, the works of I. Borbych [1], I. Yermakov [4], N. Kalinina [5] are devoted to defining the essence of the phenomenon of social competence. Peculiarities of self-realization of a personality in a society have been studied by V. Radul, I. Krasnoshchok, I. Lebedyk [9], as well as A. Kuptsova, O. Sakovych, T. Kondrashevska, L. Loginova, S. Miruk [13]. O. Lytovchenko has studied the upbringing of a socially competent personality in an out-of-school educational institution [6]. Problems of non-formal education have been considered by $\mathrm{E}$. Huseynova, Y. Lukyanova [3], S. Ovcharenko [7], N. Pavlyk [8], P. Coombs, M. Ahmed [14], L. Sigayeva [11]. The essence and content of the concept of "pedagogical conditions" have been studied by N. Tverezovska and L. Filippova [12], O. Brazhnych [2], N. Parkhomenko, R. Seryozhnikova and L. Yakovytska [10]. However, the systematization of the results of the scientific research, related to the issues of nonformal education and its impact on the formation of the social competence of students, allows to state that sociopedagogical conditions of the formation of social competence of a personality in the space of non-formal education still remain unexplored and therefore relevant.

The purpose of the article is to substantiate the sociopedagogical conditions of the formation of high school students' social competence in the space of non-formal education.

Research methodology. In order to implement the defined tasks, the following research methods have been used: content analysis at different stages of socio-pedagogical conditions, systematization, generalization of sociological, psychological and pedagogical literature in order to clarify the content of basic concepts of research of sociopedagogical conditions of high school students' social competence in the space of non-formal education; theoretical generalization of the investigated process.

The results of the scientific research. The formation of social competence plays an important role in both human life and society. Its successful implementation defines the extent to which a personality is able to realize the abilities, inclinations; reach social maturity, be useful to a society, create favorable living conditions. At the same time, the socialization of individuals, carried out on the basis of social competence, contributes to the proper stability and development of society as a whole unit. Therefore, the institutions of socialization should put their efforts to creating conditions for becoming a socially competent personality, capable of social self-realization in society, able to comprehend their own lives in the context of society, capable of tolerant communication and cooperation with others, ready for constructive actions in various life situations.

Relatively to the topic of the research, the category "social competence of a personality" is interpreted as the ability of active life self-determination, self-realization and active social interaction based on the acquired knowledge, skills, abilities and values. At the same time, social competence as an integrated characteristic of a personality implies a set of certain qualities, abilities, social knowledge and skills, experiences, emotional and value orientations and beliefs. Besides, it is concerned with providing an opportunity to interact actively with society, establishing contacts with various groups and individuals, participating in socially significant projects and performing productively various social roles. Social competence of a personality is determined by the ability to navigate in social situations, to determine correctly the personal characteristics and emotional state of others, the ability to choose the adequate ways of communication and to implement them during the interaction. After the thorough study and analysis of the scientific investigations it has been determined that social competence involves the assimilation of ethical norms as the basis for the construction of individual interpersonal and intrapersonal social relations.

In our study, the central concept is "socio-pedagogical conditions", which are applied in a specific type of social relations - socio-pedagogical reality. Modeling the process of the formation of senior students' social competence in the space of non-formal education have made it possible to define that the driving forces of this process are the implementation of socio-pedagogical conditions: 1) stimulating the subjective position of senior students; 2 ) providing the socio- 
pedagogical support and monitoring; 3) modernization of the content, forms and methods of non-formal education; 4) organization of the amateur space and assistance.

It is important that the implementation of the sociopedagogical conditions of the formation of social competence of high school students in the space of non-formal education has been aimed at completing the following tasks:

the formation of motivation to succeed has been carried out through the stimulation of the subjective position of high school students;

the formation of socially important knowledge in high school students and assistance at overcoming the difficulties of socialization have been implemented through the socio-pedagogical support;

the formation of a set of qualities, necessary for the interaction with the social environment (social activity has been implemented on the basis of high school students' activity in the micro-society of non-formal education, using modernized content, forms and methods of non-formal education);

- $\quad$ the formation of a system of social values of high school students has been carried out through the organization of the amateur space and assistance.

The implementation of the socio-pedagogical conditions of the formation of social competence of high school students has been characterized on the example of the activities of general secondary education institutions, which have participated in the formative experiment.

Thus, in the process of stimulating the subjective position of high school students, the pedagogical goal to transform students from the objects to the subjects of non-formal education has been achieved, which ensures the expediency, organization and correctness of their further activities. Hence, the stimulation of the subjective position of high school students in non-formal education implies design of group activities in non-formal education; aims at promoting high school students' awareness of the essence of social competence. Students learn to look at themselves as members of society, especially in social, economic, political and spiritual spheres of life. With this purpose there have been organized circles, studios, discussion clubs.

Various interactive forms of work, including discussions, debates, the business game "Communication", etc. have been used to motivate and stimulate the subjective position of high school students during classes. Trainings "Learning to Understand Others", "Problems of Social Communication", "Personal Qualities of a Member of Society", "Growing up in Society", "Motivation of Personal Growth", "Learning to be Active" have been organized. In the classes and during the trainings, high school students have studied the algorithm of initiative: to assess the circumstances; to focus on items to be changed; to suggest ways to solve a problem (initiating, setting a goal); to think about how to achieve a goal (implementing the proposed initiative), to plan actions; to show strong-willed efforts for independent activity, to take responsibility for the actions and deeds.

In the process of stimulating the subjective position, high school students have learned to initiate issues that need to be resolved, independently plan and organize activities to achieve goals, evaluate results, and correlate the result of collective activity with personal contribution to its achievement. Analysis of common activities and self-analysis of a personal contribution helps students realize that obtaining the desired result depends on themselves, on their ambitions and efforts. In this way senior students have been motivated to succeed.

It should be noted that the formation of motives for reaching success in non-formal education doesn't involve certain forms of activity of high school students. The corresponding motivation has been formed in the process of realization of the following types of work:

selection of tasks that create a special atmosphere in the group, an elevated state; and relieve stress; uttering one's own emotional state in the most tensed, problematic situations; demonstration of the diversity of the experienced emotions by a teacher, speaking them aloud to students (demonstration of their own emotional openness); involvement of students in the collective and group forms of activity; participation in situations of self-knowledge and self-esteem;

- $\quad$ organization of acceptance and understanding the purpose of activity by students; organization of clear vision of students' outcomes of activities, resources (information, skills, abilities);

- $\quad$ creation of problem situations; conducting individual and collective conversations with high school students; use of creative tasks in social situations; creating a situation of success in social situations; organization of independent, self-educational activities of students;

- $\quad$ use of extrapolation in educational activities; use of cognitive games and game situations, etc.

Thus, stimulating the subjective position of high school students in non-formal education provides different ways to motivate them, the formation of motives for success in personal and professional self-determination.

The facility of the socio-pedagogical support and monitoring has been intended to form social intelligence in high school students. The socio-pedagogical support in the described study has been realized in the form of interaction between a social educator and a high school student on the basis of predicting the prospects of students' behavior and self-expression in the social situation of development; it has aimed at providing the most appropriate help and support; encouraging students for successful moving forward in their personal and professional self-definition, also an incentive to be active in the process. The practice of socio-pedagogical support in the space of non-formal education, having its specificity, has intended primarily at assistance for high school students in the system of social relations, demonstration them new models of interaction with themselves and the world, ways of overcoming the difficulties of socialization and methods of self-knowledge.

In the process of providing socio-pedagogical support for senior students, targeted at forming their social competence in the space of non-formal education, the following forms of work have been used: optional class "Debate"; cognitive trainings: "Learning to Understand Others", "Problems of Social Communication", "Personal Qualities of a Member of Society", "Growing up in Society", "Motivation of Personal Growth", "Learning to be Active"; socio-psychological trainings: "Effective Communication and Teamwork", training "Conflict and Communication", "I am Unique"; creation of social and communicative situations; interactive methods; project method; role games; video lectures; search expeditions and students' own cognitive research, etc. 
The socio-pedagogical support of high school students in the context of the formation of social competence has been designed at supporting them in the system of social relations, teaching them new models of interaction with themselves and the world, overcoming the difficulties of socialization. It should be stressed out that the socio-pedagogical support has always been personalized, despite the fact that teachers usually work with a group of students, staff and others. In the process of socio-pedagogical support, knowledge of social competence has been formed, which allows high school students to enter the world of social relations.

Modernization of the content, forms and methods of nonformal education has been carried out in the context of the society's current trends. Thus, the main organizational forms of non-formal education, intended to develop social activity of students include: sightseeing tours, educational tourism, presentations, trainings, courses, studios, master classes, creative workshops, round tables, video lectures, organization of common activities, sections, circles, clubs, volunteer activities, amateur art groups, sports sections, dialogue groups, participation in public movements and organizations, programs, aimed at social development (personal development trainings, communicative competence, effective communication, etc.).

In particular, in the framework of the development of high school students' social activity as a component of social competence, the space of non-formal education has been created by means of the following modernized organizational forms: intellectual development sector (circles: intellectual "Erudite", informative "Web-design", Club of gifted students), physical development sector (volleyball, basketball, football, aerobics, tourist activity: organization of sports and entertainment excursions, travel), the sector of creative development (studios: vocal, theater, radio studio, dance studio, circles: art "Palette", vocal "Rainbow", choreographic; ensembles: vocal, vocal-instrumental, projects: "In the artist's studio"), the sector of tourism and regional studies (circles: "World of Tourism"; museums: "Museum Room of Juliusz Słowacki"), the sector of patriotic development (circles: "Cossack Gart", "Falcon", "Jura", "School of Security", museums: "Museum of Military Glory"; courses: local history course "Ternopil Regional Studies", excursion and tourist routes). The project "Democratic School" should be highlighted, because it has been implemented in the space of school self-government of high school students. The issue of a weekly radio newsletter has been organized, reporting of students' self-government on the website of the educational institution, etc. A number of organizational forms of nonformal education in our research and experimental work have been saturated with dialogical methods and techniques.

The organization of space of the amateur activities and assistance has been expected to form a system of social values of high school students in the process of students' government and volunteer activities. It must be noted that the special value of students' self-government in the experimental educational institutions is that high school students have been seriously concerned with the essence of their social rights and responsibilities. It has resulted in the increased civic activity, self-awareness, life competence, well-formed value-semantic sphere. Establishment of the effective system of self-government in the institution of non-formal education has contributed to the acquisition of the necessary knowledge, skills and experience of social action by senior pupils. Therefore, the activities of students' government in the educational institution have formed a kind of model of the micro-society, within which students have had the opportunity to learn social communications, social skills and abilities that are typical of future life, revealing their personal and professional self-determination.

While forming the system of values of non-formal education, in the activities of student government, there have been realized the following forms of work: competitions "social projects", contest "Leader of the Year", forum-theater, discussions, debates, the project "Democratic School", the conference "16 Days against Violence", the Christmas Nativity Scene, the social action "Merry Breaks", the marathon "School is a Territory of Health", the marathon "Know Today to Live Tomorrow", flash mobs, quests, festivals, etc. They have been implemented predominantly through participation in self-governing institutions (parliament, departments, and clubs). The content of students' government has been determined not by the influence of teachers, but the characteristics of different types and functions of students' self-governing activities.

It is important that students' self-government ensures the mastery of key life competencies by high school students, develops their resilience, shows them active lifestyle; teaches to respond adequately to changes, self-improvement and success.

Another area of the formation of social values of high school students as a component of their social competence is presented with volunteering. The social activity of schoolchildren is favorable for expanding the space of social interaction, challenging oneself in the future occupation and choosing the further direction. Volunteer practice has helped students to perform the work assigned to them of their own free will, it has given students the opportunity to realize themselves as members of society, community, school micro-society; a chance to decide on a future profession and develop a sense of moral obligation after the completed assignment.

It is important that the participation of high school students in the volunteering activity allows them to realize their current needs for self-determination and self-realization in a group of like-minded people (reference group), not only feel the comfort of coordinated teamwork, but also show initiative and activity, assert their competence, increase selfesteem and earn authority on a value basis, gain positive experience of social interaction. As a result, high school students have explored more about real life, learned to understand the needs and problems of others, to take into account the causes and consequences of various phenomena of social life, as well as actions and behavior.

Student social projects and charitable actions have had a great educational potential - participation in them has contributed to the formation of the need to make good, help the socially vulnerable; it has fulfilled students' leisure with meaningful useful activities, distracted them from bad habits; it has formed social competence and values in accordance with life, health, family, hometown or village. The value potential of volunteering has been manifested in the improvement of students' evaluative attitudes and their social relationships.

The most important role of a social educator in the space of non-formal education correlates with mediator's skills in student social conflict situations (government agencies, nongovernmental organizations and the local community) when solving current socio-pedagogical problems of volunteering. Thus, the teacher has acted as a mediator engaging students, as well as at the request of their parents (families) into the 
volunteer movement; also as a coordinator/ a consultant in the implementation of the objectives of groups of student volunteers. These roles presuppose fulfilling the space of non-formal education with charitable content, as well as involving students in the various types of social and valuable activities; the formation of initiative groups of charitable orientation.

It should be outlined that the organization of space of the amateur activity and assistance have contributed to the formation of social competence of high school students, as far as they have learned to make their own choices and set their own socially important goals, make individual and collective decisions, taking into account not only their own interests and needs but also those ones, related to society and state.

The analysis of the role and importance of non-formal education as a factor in the formation of social competence of high school students provides grounds for formulating the following conclusions.
Conclusions. Thus, the implementation of the outlined socio-pedagogical conditions (stimulating the subjective position of high school students, providing sociopedagogical support and monitoring, modernization of the content, forms and methods of non-formal education, organization of the amateur space and assistance) in the course of research and experimental work has promoted the shift of the students' position from the objects to the subjects of educational and developmental influences, they have managed to become the agents of self-knowledge, self-development and self-realization, learning to set the socio-value vector of this process. The determined socio-pedagogical conditions also have contributed to the formation and implementation of certain components of social competence of high school students; and the acquired social knowledge, formed motives, values, behavior have been transformed from the subject of knowledge into a defined lifestyle.
1. Борбич Н. В. Формування соціальної компетентності студентів педагогічних коледжів: автореф. дис. ... канд. пед. наук: спец. 13.00.05 «Соціальна педагогіка». Київ, 2013. 22 с.

2. Бражнич О. Г. Педагогічні умови диференційованого навчання учнів загальноосвітньої школи: дис. ... канд. пед. наук: 13.00.07 «Теорія і методика виховання» / О. Г. Бражнич. Кривий Ріг, 2001. -238 с.

3. Гусейнова Е. І., Лук'янова Ю. М. Неформальна освіта як важливий елемент безперервної освіти. Педагогічні науки. 2012. URL: NPE_2012/Pedagogica/4_106261.doc.htm.

http://rusnauka.com/11_

4. Життєва компетентність особистості: від теорії до практики: наук.-метод. посіб. / за ред. I. Г. Єрмакова. Запоріжжя: Центуріон, 2005. $640 \mathrm{c}$.

5. Калинина Н.В. Развитие социальной компетентности школьнивождение. Ульяновск: УИПК ПРО, 2004. 228 с.

6. Литовченко О. В. Виховання соціально компетентної особистості в позашкільному навчальному закладі. Шлях освіти. 2009. №4. C. $28-31$.

7. Овчаренко С. Г. Неформальна освіта - необхідний елемент сучасної освітньої системи. URL http://dialog.lviv.ua/files/champions_final_conference.pdf.

8. Павлик Н. П. Неформальна освіта / Non-Formal Education. Енциклопедія прав людини: соиіально-педагогічний аспект: [колективна монографія]/кол. авт., за заг. ред. Н. А. Сейко; ков в образовательной среде: психолого-педагогическое сопро-

\section{EРАТУРА}

відп. ред. Н. П. Павлик. Житомир: Волинь, 2014. 220 с. С.120 124.

9. Радул В.В., Краснощок І.П., Лебедик І.В. Дослідження особливостей самореалізації особистості: монографія. К.: ІмексЛТД, 2009. $352 \mathrm{c}$.

10. Серьожнікова Р. К., Пархоменко Н. Д., Яковицька Л. С. Основи психології i педагогіки: навчальний посібник / P. К.Серьожнікова, Н. Д.Пархоменко, Л. С.Яковицька. - К.: Центр навчальної літератури, 2003. - 243 с.

11. Сігаєва Л.Є. Розвиток освіти дорослих в Україні (друга половина XХст.-початок XXI ст.: монографія/за ред. С.О. Сисоєвої/АПН України, Інститут педагогічної освіти і освіти дорослих АПН України.-К.: ТОВ ВД «ЕКМО».-2010.-420 с.

12. Тверезовська Н., Філіппова Л. Сутність та зміст поняття «педагогічні умови». URL: http://nbuv.gov.ua/ portal/Soc_Gum/Npd/2009_3/Tverezovska.pdf.

13. Участь дітей та молоді в процесах.прийняття рішень: метод. посіб./А. Купцова, О. Сакович, Т. Кондрашевська, Л. Логінова, С. Мірук. К.: АртБат, Такі Справи, 2012. 112 с.

14. Coombs P., Ahmed M. Attacking Rural Poverty: How non-formal education can help. Baltimore: John Hokins University Press.1974.-P.292

15. Ruchen D. S. Key Competencies for a Successful Life and a WellFunctioning Society. Hogrefe \& Huber Publishers, Germany, 2003. P. 4-5.

\section{REFERENCES}

1. Borbych N.V. Formation of Social Competence of Students of Pedagogical Colleges: author's ref. dis. ... Cand. ped. Science: special. 13.00.05 "Social Pedagogy". Kyiv, 2013. 22 p.

2. Brazhnych O.G. Pedagogical Conditions of Differentiated Learning of Secondary School Students: dis. ... Cand. ped. Sciences: 13.00.07 "Theory and Methods of Education" / O.G. Brazhnych. Kryvyi Rih, 2001. - 238 p.

3. Huseynova E.I., Lukyanova Yu.M. Non-formal Education as an Important Element of Continuing Education. Pedagogical sciences. $2012 . \quad$ URL: http://rusnauka.com/11_ NPE_2012/Pedagogica/4_106261.doc.htm.

4. Lifestyle Competence of Personality: from Theory to Practice: scientific-methodological manual / ed. by I.G. Yermakov. Zaporizhia: Centurion, 2005. $650 \mathrm{p}$.

5. Kalinina N.V. Development of Social Competence of Schoolchildren in the Educational Environment: Psychological and Pedagogical Support. Ulyanovsk: UIPK PRO, 2004. 228 p.

6. Litovchenko O.V. Education of Socially Competent Personality in Out-of-School Educational Institution. Shlyakh osvity. 2009. №4. Pp. 28-31.

7. Ovcharenko S.G. Non-formal Education is a Necessary Element of a Modern Educational System. URL: http://dialog.lviv.ua/files/champions_final_conference.pdf.
8. Pavlyk N.P. Non-Formal Education. Encyclopedia of Human Rights: Socio-Pedagogical Aspect: [collective monograph] / col. author, ed. by N. A. Seiko; resp. ed. N.P. Pavlyk. Zhytomyr: Volyn, 2014. 220 p. P.120-124.

9. Radul V.V., Krasnoshchok I.P., Lebedyk I.V. Research of Features of Self-Realization of a Personality: monograph. Kyiv.: Imeks LTD, 2009. $352 \mathrm{p}$

10. Seryozhnikova R.K., Parkhomenko N.D., Yakovitskaya L.S. The Basics of Psychology and Pedagogy: manual / R.K. Seryozhnikova, N.D. Parkhomenko, L.S. Yakovytska. - Kyiv: Tsentr navchal'noyi literatury, 2003. - 243 p.

11. Sigaeva L.E. Development of Adult Education in Ukraine (second half of the XX century-beginning of the XXI century: monograph / edited by S.O. Sysoeva/Academy of Pedagogical Sciences of Ukraine, Institute of Pedagogical Education and Adult Education of the Academy of Pedagogical Sciences of Ukraine. - Kyiv .: LLC VD "EKMO" .- 2010.-420 p.

12. Tverezovska N., Filippova L. The Essence and Content of the Concept of "Pedagogical Conditions". URL: http://nbuv.gov.ua/portal/Soc_Gum/Npd/2009_3/Tverezovska.pdf.

13. Participation of Children and Youth in Decision-Making Processes: manual /A. Kuptsova, O. Sakovich, T. Kondrashevskaya, L. Loginova, S. Miruk. Kyiv: ArtBat, Taki Spravi, 2012. 112 p. 